\title{
The taxonomy, life cycle and pathology of Sarcoptes scabiei and Notoedres cati (Acarina, Sarcoptidae): A review in a Fennoscandian wildlife perspective
}

\author{
Morten Kraabbl', Vegard Gundersen', Kirstin Fangel' and Kjetil Olstad'
}

Kraabøl M, Gundersen V, Fangel K, Olstad K. 2015. The taxonomy, life cycle and pathology of Sarcoptes scabiei and Notoedres cati (Acarina, Sarcoptidae): A review in a Fennoscandian wildlife perspective. Fauna norvegica 35: 21-33.

Mites constitute an old cosmopolitan group, abundant in various terrestrial and aquatic habitats of considerable environmental variations. The majority of mites are free-living, whereas some have evolved parasitic relationships with a variety of animals either as endo- or ectoparasites. The ectoparasitic and skin burrowing Sarcoptes scabiei and Notoedres cati, cause sarcoptic and notoedric mange among a variety of mammalian species, including humans. In a non-adequate host these mites lead to pseudo-scabies which is often self-curable. The aim of this review is to provide an overview of recent knowledge on the taxonomy, life cycles and pathology of these two mites, which are of relevance to Fennoscandian wildlife, by considering knowledge on transmission vectors, host immunology, and some documented outbreaks. These mites affect the health and survival of mammals in four ways; 1) skin tissue damages, 2) loss of body fluids, 3) allergic reactions and 4) secondary bacterial infections. A short-term effect of outbreaks is usually high mortality, and long-term effects vary from extinction to biased population structure to no effect at all. Red foxes are generalist predators that are important end-hosts for mites that develop disease depending on their immunity status, and transmit mites to other hosts. Outbreaks of mange may possibly have ecological consequences on a wider scale. In an endangered species, like the arctic fox or Eurasian lynx, loss of only a few individuals can be critical. It might be wise for management authorities to develop emergency plans to minimize consequences of outbreaks of sarcoptic or notoedric mange in threatened species such as the arctic fox and the lynx.

doi: 10.5324/fn.v35i0.1652. Received: 2013-11-15. Accepted: 2015-11-30. Published online: 2015-12-17. ISSN: 1502-4873 (printed), 1891-5396 (electronic).

Keywords: Ectoparasites, mange, mites, Notoedres cati, outbreak, Sarcoptes scabiei, scabies, zoonosis

1. Norwegian institute of nature research, Fakkelgården, N-2624 Lillehammer, Norway

Corresponding author: Morten Kraabøl

E-mail:morten.kraabol@nina.no 


\section{INTRODUCTION}

Mites (Acari or Acarina) are among the oldest animal groups with fossils dated back to early Devonian (Norton et al. 1988; Kethley et al. 1979). So far, 45000 species in several hundred families have been described, both fossils and extant. Three major lineages are currently recognized; Opilioacariformes, Acariformes and Parasitiformes (Krants 1978; Johnston 1982; Evans 1992). Mites are cosmopolitans and abundant in various terrestrial, marine and fresh water habitats, ranging from cold polar and alpine regions through deserts, tropical lowlands and subterranean springs with temperatures up to $50^{\circ} \mathrm{C}$ (Fields 1992). They are also commonly found as deep as $10 \mathrm{~m}$ in mineral soil and have been collected from $5000 \mathrm{~m}$ deep seatrenches.

The majority of mites feed on plant juices or prey on other arthropods, but many species have complex parasitic associations with different animals. Several mammals are target hosts to numerous parasitic mites causing varying degrees of mange (also termed acariosis or scabies). The majority of parasitic mites complete their life span as ectoparasites, but some have become endoparasites, invading ears, lungs, nose or other internal tissues of animals. The skin burrowing ectoparasite Sarcoptes scabiei (Linneaus, 1758) and Notoedres cati (Hering, 1838), cause mange among many different mammals, including humans (Walton et al. 2004; Heukelbach \& Feldmeier 2006). S. scabiei forms to some extent speciesspecific and host-adapted varieties, infecting canids, felids and ungulates (Walker \& Stacheki 1996), but a variety of other animal groups are also infected (Pence \& Ueckerman 2002). $N$. cati is far less studied and have been reported to host on fewer species, but is relevant in our review because the species occur in Europe, often infect domestic animals and pets, and the presence of the species is often in close relation to human activities. $N$. cati infects primarily felids, Lagomorphs, rodents and to some extent humans. This ectoparasite has not yet been classified in host-specific varieties, but they most likely do exist (Pence et al. 1982). Several epizootics of scabies, both due to $S$. scabiei and N. cati, have demonstrated severe impacts on the size and structure of numerous animal populations (Walton \& Holt 2004). Among humans, $300 \times 10^{6}$ cases of scabies infestations worldwide occur each year (Walker \& Johnstone 2000). In some less developed areas, scabies represent a considerable public health problem, with higher prevalence than diarrhea and upper respiratory diseases (Anonymous 2000). Most publications on human scabies focus on intrahuman vectors and scabies prevalence relates mostly to living conditions. Although animal-to-human transmission vectors (zoonosis) of mange-causing mites probably are of limited relevance to human health, it is significant to animal handlers, veterinary practices and hunters who may be in regular contact with infected animals.

The purpose of this article is to review recent knowledge on the taxonomy, life cycle and pathology of the two mites by considering recent studies of transmission vectors, immunology and ecological effects on parasitized wildlife populations. Our aims are:

1) Provide a brief review of the general phylogeny, taxonomy, biology and pathology of the two mites with emphasis on Sarcoptes scabiei.

2) Disease effects on hosts at an individual level

3) Disease effects on hosts at population level with emphasis on the red fox case in Fennoscandia

\section{A brief review of $S$. scabiei and N. cati}

\section{Phylogeny of mites}

There is some discussion whether the genus Acari is monophyletic or diphyletic. Lindquist (1984) and Evans (1992) suggested that Opilioacariformes and Parasitiformes are sister groups, and that both form a sister group to Acariformes (Weygoldt \& Paulus 1979, Shultz 1990, Weygoldt 1997) favored a monophyletic inheritance, while Dunlop (1996) favored a diphyletic inheritance, but the problem remains unsolved.

The Opilioacariformes consists of one order (Opilioacarida) with one family (Opilioacaridae), constituting about 20 known species. The Acariformes contains more than 300 families and about 30,000 species in two major lineages; the Sarcoptiformes (Oribatida and Astigmata) and Trombidiformes (Prostigmata). The Parasitiformes consists of three orders; Ixodida $(850$ species), Holothyrida (30 species) and Mesostigmata (10,000 species).

\section{Taxonomy}

Both S. scabiei and N. cati belongs to the order Astigmata and family Sarcoptidae. Several subtypes, or varieties (var.), have been reported such as S. scabiei var. canis in dogs, var. vulpes in red fox and var. hominis in humans. No diagnostic morphological features have been reported to reliably distinguish between supposed varieties from different hosts. The taxonomy of S. scabiei is still uncertain, but most authors retain a single but variable species with host-specific preferences (Fain 1968, 1978, 1994; Pence et al. 1975; Andrews 1983; McCarthy et al. 2004). Heukelbach \& Feldmeier (2006) reported a general agreement of $S$. scabiei as a single species that has evolved adaptations to infect a variety of mammals with limited cross-infestations between different hosts. Curtis (2004) reported that S. scabiei var. canis has been isolated from other hosts and experimentally established on both rabbits, guinea pigs, sheep, goats, calves, cats and humans. Distinct geographic variations in DNA sequences of $S$. scabiei from Alpine chamois (Rupicapra rupicapra), Pyrenean chamois (R. pyrenaica) and red fox (Vulpes vulpes) from different localities in Italy and Spain indicate an ongoing process of differentiation (Berilli et al. 2002). However, limited gene exchange between the mite populations was probably due to genetic structuring of local populations (Brilli et al. 2002), and 
not related to host-specific adaptations. In Fennoscandia little is known regarding the occurrence of variants from S. scabiei and $N$. cati. Processes relating to coevolution between hosts and parasites are well known (Anderson \& May 1982), but remains unclear for ectoparasites and their hosts. Parasites engage differently with their respective hosts, but a common feature is that natural selection tends to favor defense (from the hosts) and counter-defense (by the mites) by means of coevolution. Such processes may lead to increased differentiation and host specificity. Microsatellite data of $S$. scabiei on dogs and humans gave strong indications of host-specific species differentiation (Walton et al. 1999). It is likely that such adaptations are still ongoing processes in free-ranging canids and felids in Fennoscandia. As a conclusion, the exact nature of host specific adaptations and species differentiation is not fully understood, and further research is needed.

\section{Life cycle and transmission}

Life cycles, biology and pathology of S. scabiei and N. cati are quite similar (e.g. Walker \& Stacheki 1996), but the life cycle of $N$. cati has not yet been described in detail (Anonymous 2015 a, b). Thus, the following description is most valid for $S$. scabiei: They mate on the dermis of a host and males continue to explore the skin for several days seeking unfertilized females after mating (Heilesen 1946; Mellanby 1985). Females lay 2-4 eggs (0.10-0.15 mm diameter) daily during their 4-6 weeks life-time. The eggs are laid in a ca. $1 \mathrm{~cm}$ long burrow in the stratum corneum, sometimes reaching down to the boundaries of the stratum granulosum of the epidermis. Less than $10 \%$ of the eggs laid result in mature mites (Orion et al. 2006). A hexapod larvae emerges 2-4 days after the egg has been laid, it leaves the burrow and wanders about on the host's body to complete maturation within 14-17 days (Burkhart et al. 2000). The larva forms a new pocket-burrow either in conjugation with its natal burrow or somewhere else. They feed and molt into two eight-legged nymph-adult stages termed protonymphs and tritonymphs. After 10-14 days the last molt takes place and the nymph appears as an adult male or female mite.

Transmission between different hosts occurs during the free-living nymph and adult stages of females on the skin. All stages after hatching can penetrate intact epidermis. Penetration is achieved by secreting enzymes that dissolve the skin, which is subsequently ingested. Skin entry may occur less than 30 minutes after transmission to a new host (McCarthy et al. 2004). Total life span may vary from a few days to several weeks, depending on host species, temperature and humidity. S. scabiei var. hominis fulfill their life span on humans, but $N$. cati does not burrow into human skin although intense pruritus develops within a few hours following initial contact (Chakrabarti 1986). Nymphs and adults of both species feed on lymph fluids that excrete from the dermal tissue into the burrows. Female mites are capable of moving $2.5 \mathrm{~cm}$ per minute on the skin of a host. Movement direction is determined by odor and thermal stimuli (Orion et al. 2006).

\section{Viability of $\int$. scabiei without host attachment}

Both adults and other developmental stages of S. scabiei var. canis off the host have been experimentally demonstrated to survive for several days and weeks depending on (relative) humidity and temperature (not known for $N$. cati, Arlian et al. 1984; Arlian 1988). At low temperatures between 10 and $15^{\circ} \mathrm{C}$ combined with high relative humidity (45-97\%), the off-host life span of all life stages varied between 5 days and 3 weeks. This survival was reduced at higher temperatures even at high humidity. At $21^{\circ} \mathrm{C}$ and $40-80 \%$ relative humidity, S. scabies was able to survive and capable of skin penetration for 24-36 hours. In general, mite infectivity decreased with increasing time off the host. Burgess (1994) reported similar relationships between temperature, humidity and longevity of sarcoptic mites, and Mellanby (1985) found that mites were unable to move and penetrate skin below $20^{\circ} \mathrm{C}$.

In practice it is not possible to define if infected animals have been subject to direct or indirect transmission of $S$. scabiei. However, it seems reasonable to anticipate indirect transmissions especially in the southern parts of Fennoscandia, where climatic conditions are suitable for survival in the environment. Distinct passages in dense vegetation, or inside dens, might be potential sites for indirect transmission between animals passing through at the same location.

\section{Mammalian hosts}

Sarcoptes scabiei has been reported from more than 100 wild and domestic mammals of seven orders (Arlian 1989; Bornstein et al. 2001; Balestrieri et al. 2006). It is responsible for epizootic diseases in wild canids in North America, Europe and Australia, in wild cats in Europe and Africa, in wild ungulates and wild boars (Sus scrofa) in Europe, in wombats and koalas in Australia, and in great apes and various wild bovids in Africa (i.e. Pence \& Ueckerman 2002). Examples of canids affected are the red fox (Holt \& Berg 1990; Mörner 1984, 1992; Little et al. 1998; Deem et al. 2002; Davidson et al. 2008), the arctic fox (V. lagopus, Mörner 1992), the gray wolf (Canis lupus, Todd et al. 1981), and the domestic dog (C. familiaris, Voigt 2005). Ungulates affected are cattle (Bovis spp., Soll et al. 1992), swine (Sus spp., Davis \& Moon 1990 a, b), several sheep and goat species (Curtis 2004, González-Candela et al. 2004), red deer (Cervus elaphus) and roe deer (Capreolus capreolus, Oleaga et al. 2008a, b). Several felids, such as the domestic cat (F. sylvestris, Guaguère 1999) and the lynx (Lynx lynx, Dobias 1981; Jeu \& Xiang 1982; Mörner 1992; Ryser-Degiorgis et al. 2002) have also been occasionally infested. Infections have also been reported in the badger (Meles meles, Holt \& Berg 1990), pine marten (Martes martes, Holt \& Berg 1990; Mörner 1992) and European rabbit (Oryctolagus cuniculus, Millàn 2012). A recent study from Poland investigated 10 species of carnivores, and sarcoptic mange infection where identified on red foxes $(19 \%)$, badgers $(9 \%)$, wolves $(7 \%)$, raccoon dogs $(6$ 
$\%)$, stone marten (5\%) and lynx (2\%) (Kolodziej-Sobocinska et al. 2014). They found that rate of infection was correlated with the sum of ecological and behavioral features, indicating the occurrence of between-species transmission that again may increase the spread of infection. $N$. cati is far less studied and thus reported from fewer species. It is primarily found on wild and domestic felids and rabbits, including the European lynx (Dobias 1981). It has occasionally been found on humans (Chakrabarti 1986). Notoedric mange resembles sarcoptic mange in terms of a debilitating and multisystemic disease course (Klein Serieys et al. 2013). Infections involving both mite species have been reported from one lynx in Switzerland (Ryser-Degiorgis et al. 2002). A recent outbreak of notoedric mange lead to a population decline in the bobcat (L.rufus) in Southern California, followed by intraspecific spreading of the disease northwards in USA (Klein Serieys et al. 2013).

In Fennoscandia, the primary host species in concern regarding both species is the red fox (hosting S. scabiei) and lynx (hosting N. cati). A surveillance program for red foxes should be designed to cover local as well as regional changes of prevalence. According to oral reports from hunters, there are local variations in mange prevalence among red foxes. Considering the wide-ranging and potentially cascading effects on mammalian fauna (i.e. predator-prey relationships), it seems important to monitor the fluctuating situation on a local and regional scale. The European lynx and the arctic fox is of particular interest regarding the vulnerable status in Fennoscandia.

\section{Disease effects on host at individual level}

\section{Human scabies and the risk of zoonosis}

Human scabies is a well-known disease since antiquity (Haas et al. 2005). The Italian physician Giovan Cosmito Bonomo and the (apothecary) pharmacist Diacinto Cestoni revealed the relationship between mites and the scabies disease (1687), and showed for the first time in history that a disease was caused by a "non-visual" organism (Ramos-e-Silva 1998). Both $S$. scabiei and $N$. cati are known to infest humans in contact with mangy animals (Chakrabarti 1986; Walton et al. 2004; Beck 2005). Companion dogs and domestic cats are believed to be the original source of human infestations, and several outbreaks of limited health impact are known (Fain 1978; Chakrabarti 1986; Mitra et al. 1993; Morsy et al. 1994; Burroughs \& Elston 2003; Heukelbach \& Feldmeier 2006). Pseudo-sarcoptiosis occurs when the mite infest a non-adequate host, after contact with mange-affected livestock, pets and game animals (Birk et al. 1999). Hunters in contact with animals may develop short-term pseudo-scabies with characteristic lesions. Such lesions are self-curable and commonly referred to as "cavalry man's itch" or "pig-handler's itch" (Burgess 1994; Birk et al. 1999), and cause far less severity than developed human scabies. Pseudoscabies has shorter incubation period than human scabies which is caused by S. scabiei var. hominis. The topographic distribution of skin lesions also differs between these two types of infestation, Pseudo-scabies usually occurs in body areas that have been in direct contact with an infected skin or fur of the host (Heukelbach \& Feldmeier 2006). Pseudo-scabies tends to be self-limiting on humans due to responses in the immune system. Normally, treatment is not required in such cases (Fain 1978; Chakrabarti 1985; Arlian 1989; Burgess 1994; Hay 2004; Walton et al. 2004, but see Curtis 2004). ). Human scabies has thus limited relevance for hunters and animal handlers in Fennoscandia today.

Development of human scabies requires infestation with $S$. scabies var. hominis and limited or absence of proper medical care over time. Normally, a parasite burden of 10-12 mites appears during the first 3 months of infestation (Mellanby 1985; McCarthy et al. 2004). Primary infestation is described by delayed onset of sensitization and symptoms, contrary to pseudo scabies. If humans later are exposed to a secondary infestation of mites hypersensitivity usually occurs within a day (Mellanby 1944), even though the parasite burden is usually lower compared to the first infestation. Some degree of protective immunity may explain the reduced parasite burden in secondary infestations and may as well explain why such re-infestations are rare (Lalli et al. 2004).

Crusted scabies in humans is a far more severe and chronic condition characterized by a large parasitic burden, sometimes several millions mites (McCarthy et al. 2004). It was formerly termed Norwegian scabies on account of its first recognition in Norway in 1848 among patients with leprosy (Danielssen $\&$ Boeck 1848). Clusters of infestations occur in patients with weak immune responses (immunocompromised individuals), in patients and staff at hospitals or in nursing homes for elderly and in overcrowded areas in developing countries (Chosidow 2000). There is no evidence for increased mite virulence among such patients (subjects), and the heavy parasite burden is most likely caused by the weakened state of health of the host. Crusted scabies appear as hyperkeratotic lesions on hands, feet, ears and scalp. Epidemics have been reported from several wards of mentally or physical disabled humans with immunological deficits or inability to eliminate mites by scratching, e.g. mongoloids (Hubler 1976). Crusted scabies leads to high mortality due to secondary sepsis (Huffam \& Currie 1998; Hulbert \& Larsen 1992).

\section{General pathology}

Mites affect the health of free-ranging mammals in four ways; 1) burrowing mites damage skin tissues which lead to dermatitis with 2) loss of blood or body fluids, 3) allergic reactions and 4) secondary bacterial infections (Walker \& Stacheci 1996). Untreated and advanced scabies caused by a host-adapted variant, which is mostly the case in outbreaks in wild animals, often causes death (Alonso de Vega et al. 1998; Brotowijoyo 1987; Kemp et al. 2002).

The pathological condition of mammals infested with $S$. 
scabiei or N. cati is commonly termed sarcoptic or notoedric mange, while the popular terms "scabies" or "scab" are also frequently used. Chronic and potentially fatal mange may occur when these mites infest an adequate host and develop an increasing parasitic burden. Pseudo-scabies on the other hand, is mostly self-limiting and temporary because of the immunologically mismatch between parasite and host (Sokolova \& Lange 1992). The mite-host-specific mechanisms responsible for various outcomes of infestations are yet largely unknown, and further research is needed. Macroscopical and histological results from red foxes suggested three different disease stages (Nimmervoll et al. 2013). The first stage is characterized by extensive skin lesions, thin crusts, mild to moderate alopecia, low parasite burden, numerous eosiniophils, and slightly swollen nymph nodes. A second stage usually follows and is characterized by skin lesions, thick crusts (with or without alopecia), malodours, emaciation, heavy parasite burdens, numerous bacteria and yeasts, increased numbers of lymphocytes and mast cells and severely swollen nymph nodes. A third stage may follow the second, or in some cases the first, is described by focal lesions, absence of crusts but severe alopecia, hyperpigmentation and lichenification, absence of mites, mixed cell infiltration and rare mild lymph node enlargements. The second stage may possibly be lethal to red foxes. Survival depends on largely unknown extrinsic factors or intrinsic immunological factors affecting the animal's ability to cope with the mite infestation (Nimmervoll et al. 2013). In conclusion, development of chronic mange in wild mammals normally requires transmission of an adequate species-specific mite between conspecific hosts, and inter-specific transmission rarely result in chronic or fatal illness.

Skin lesions in recently infected individuals are characterized by excoriation, hemorrhagic crusts and patchy alopecia, epidermal mast cell hyperplasia, spongiosis, infiltrations of eosinophils and afterwards compact hyperkeratosis, parakeratosis, severe crustings and lymphocytic exocytosis (i.e. Burgess 1994). Elevated amount of white blood cells are common histopathological signs of chronic mange (Mörner 1981; Pence et al. 1983; Schmitt et al. 1987; Little et al. 1998). Notoedric and sarcoptic mange produce a similar inflammatory cell reaction in the dermis. Among felids, notoedric mange tends to concentrate in the head and shoulder region, but some exceptions have been reported (Pence et al. 1982, 1995; RyserDegiorgis et al. 2002). Sarcoptic mange tends to infest larger parts of the body, especially legs, flanks and tails. The dermal irritation that leads to itching followed by secondary infections is caused by mite feces and eggs deposited in the burrows (Droogan 1999; Chosidow 2000).

Concomitant infections of S. scabiei and endoparasites living in the gastro-intestinal tract are probably quite common (Cox 2001). Mangy individuals may be particularly vulnerable to infections by multiple parasites because they are undernourished and immunologically disarmed (Wilson et al. 2001). Malnutrition may reduce resistance and lead to increased fecundity, growth and burden of the parasite (Balic et al. 2000; Claerebout \& Vercruysse 2000). In a survey of red foxes from the Western Italian Alps, individuals with sarcoptic mange had higher prevalence of both cestode and nematode worms. This may suggest some form of active and passive interaction between ecto- and endoparasites (Balestrieri et al. 2006). Concomitant infections in scabies-infected animals may strongly increase the mortality rate.

Secondary infections are often associated with scabies infestations (Brook 2002). The risk increases during sustained infestation and gives pruritic dermatitis. Staphylococcus aureus and group A haemolytic streptococci have most frequently been found in humans (Brook 2002). These bacterial infections usually lead to cellulites, lymphangitis or aqute glomerulonephritis (Kemp et al. 2002), and may markedly increase mortality.

\section{General host immunology}

The complex immunology in the epidermis and dermis of affected hosts is not well understood at the species level (Nimmervoll et al. 2013; but see Kuhn et al. 2008), and the following generalization of host immunology is regarded to be representative to Fennoscandian wildlife. Certain components in extract from scabies mites modulate the inflammatory/ immune reaction during infestation (Arlian et al. 2003). The immune response is dominated by elevated amounts of T-lymphocytes, plasma cells, mast cells, neutrophils (Skerratt 2003a; Arlian et al. 1996, 1997, 2006; Klein Serieys et al. 2013), but have been found to differ in e.g. wombats and red foxes. Foxes display a hypersensitive response immediately following S. scabiei infection (Little et al. 1998), whereas wombats do not (Skerratt 2003b). Pigs and rabbits also differ in their inflammatory infiltrate in the dermises and involves Eosiniphils and T-lymphocyt (Davis \& Moon, 1990a; Arlian et al. 1994a, b). These differences have been explained by a desensitization of the immune system in some species infected with S. scabiei.

Goats have been found to be immune to sarcoptic mange (Tarigan 2003a, b; Tarigan \& Huntley 2005). Little et al. (1998) tested the response of red foxes to repeated infections, and concluded that resistance did not occur after a second infection after clearance of mites from the primary infection. Consequently, infection does not necessarily lead to immunity in the red fox. Humans, dogs and rabbits on the other hand are able to develop efficient protective immune responses when repeatedly exposed to live mites (Mellanby 1944; Arlian et al. 1994a, b, 1996). A long-term study of S. scabiei infected Norwegian red foxes indicate host-parasite adaptions (Davidson et al. 2008). Burrowing mites provokes mite-specific circulating antibodies and immunological memory in the T-cells and reduced parasitic burden. The immunity to re-infestations is due to both a cell-mediated immune response as well as an antibody response in the infected host (Cabrera et al. 1993). In trials, canids quickly showed antibody responses to 
re-infections quick which peaked within 8 days. Between 24 and 64 days after infestation, the immune response had cleared all scabies mites from the host (Arlian et al. 1996; Nisbet \& Huntley 2006). This immunity was caused by the memory function provided by T-cells, and is believed to be a Th2-IgE mediated response (Tarigan 2003a, b). The pronounced Th2 inflammatory responses that involve occurrence of eosinophils, mast cell hyperplasia and the onset of IgE antibodies, suggests a Type 1 hypersensitivity reaction (Tarigan 2003a, b; Van den Broek \& Huntley 2003). However, whether these responses are directly involved in the mechanism of immunity or simply induced by mites for their own benefit such as feeding are not known (Tarigan \& Huntley 2005). The role of IgE in host immunity to psaroptic scabies mite (Psoroptes ovis) has also been documented (Stromberg \& Fisher 1986; Stromberg \& Guillot 1989). The mechanisms underlying immunity responses seem to vary between species (Nimmervoll et al. 2013) and experiments with repeated infestations with $S$. scabiei show a wide range of immune responses ranging from no immunity to acquired full immunity.

\section{Disease effects on host at population level}

\section{Some effects on population dynamics}

Besides increased mortality in host populations, sarcoptic mange often lead to reduced feeding efficiency and reproduction (Borg et al. 1976). Clinical sign of accelerated muscle catabolism has also been documented (Newman et al. 2002). Scabies infested red foxes normally die after a few weeks, but some may live as long as 9 months (Mörner \& Christensson 1984; Newman et al. 2002), probably depending on several factors such as concomitant and/or secondary infections, food availability and weather. All these factors may potentially affect population dynamics due to increased mortality and reduced reproduction. A long-term study of scabies in red foxes shot by hunters in Norway indicated that the population to some degree could cope with the parasite over time. Low-grade or subclinical infections and even recoveries have been documented (Davidson et al. 2008; Nimmervoll et al. 2013). However, such trends may be unstable due to the ongoing arms race between parasites and hosts.

Baker et al. (2000) and Soulsbury et al. (2007) reported changes in the spatial organization of urban foxes during an outbreak of sarcoptic mange in England. Surviving foxes increased their ranges when neighboring groups died. The average group size declined because of mange-induced mortality.

The transmission of sarcoptic mange in wildlife population is very complex. In addition to being density-dependent it is also related to territorial conflicts in the hosts. Positive correlations between population densities and prevalence of sarcoptic mange is reported (Pence \& Windberg 1994; Skerrat et al. 1998). Direct and indirect contact between conspecifics and between different species may certainly affect the transmission rate of the sarcoptic mange (e.g. Kolodziej-Sobocinska et al. 2014). Species that have well-developed sociality (i.e. structures and behavior related to family groups and hierarchies) in red fox and arctic fox populations will probably inflict a higher number of transmission incidents compared to more solitary living species like lynx and pine marten (Martes martes). Thus, sociality is probably one of the main factors influencing the severity of sarcoptic mange outbreaks. Sarcoptic mange may alternatively be transferred indirectly by visiting or sharing den and passage sites. Den sharing seems to be an important factor affecting sarcoptic mange spread both within species like red fox and arctic fox, but also between other denning species like for example red fox, badger and to some degree the grey wolf. The individuals in a lynx population often use separate resting sites above ground and their home ranges do not overlap in the same degree compared to foxes. This, in combination with very few incidents of $N$. cati among felids in Fennoscandia, reduces the probability of mite transmission.

Intraguild predation may be an important factor for transmission of sarcoptic mange. Wolves and lynx prey upon medium-sized carnivores like red foxes, pine martens and badgers (i.e. Linnell et al. 1998; Sunde et al. 1999). This may probably explain sporadic and small-scale outbreaks among solitary species like the lynx. However, a few incidents of outbreaks within family groups may be of great influence if the population size is already reduced by other factors. In addition, infected and ill-behaving lynx may increase the rate of encounters with other felids as malnutrition and starvation alters the behavior of infected individuals.

\section{Outbreaks in general and the red fox case in Fennoscandia}

Several epizootic outbreaks of sarcoptic mange have had severe impact on wildlife species. When man introduced S. scabiei to Australia, epidemics lead to complete extinction of several wombat populations (Martin et al. 1998; Skerratt et al. 1998, 2002). Outbreaks in chamois populations in Australia resulted in $90 \%$ mortality (Farnandez-Moran et al. 1997). Changes in the population structure of red fox populations in Northern Europe were strongly linked to a high prevalence of scabies (Forchhammer \& Asferg 2000). Population of red foxes in Eastern Slovakia suffering from outbreaks of sarcoptic mange were heavily reduced (Goldova et al. 2001). It seems that mange outbreaks generally do not affect long-term population dynamics, but the short-term mortality may be severe (Pence \& Ueckerman 2002). Consequences of outbreaks may therefore be linked to the immune status of the hosts (Kolodziej-Sobocinska et al. 2014).

Inter-specific relationships may play a significant role in both prevalence and mortality. For example, sarcoptic mange in foxes may have implications for sympatric lynx populations, because habitat sharing facilitates transmission of pathogens between species, which has also been suggested for the lynx and domestic cats (Ryser-Degiorgis 2002). 
A severe and wide-ranging outbreak of sarcoptic mange in Scandinavian red foxes naive to $S$. scabiei started in the early 1970's and caused dramatic population declines in in Finland, Sweden and Norway (Holt \& Berg 1990; Mörner 1984, 1992). Sarcoptic mange spread rapidly across Scandinavia on red fox in the 1970s-1980s, initially spreading from Estonia through Finland before established on more permanent basis in Sweden about 1975 (Borg et al. 1976; Danell \& Hörnfeldt 1987; Mörner 1992). In Finland, the prevalence of $S$. scabiei in red foxes increased rapidly in 1966-67 (Borg 1978), in Sweden it was detected in 1975 (Borg et al. 1976; Danell \& Hörnfeldt 1987). The disease was observed to spread rapidly in boreal areas (low fox density), whereas it spread more slowly in agricultural areas (high fox density). Mortality due to mange was very high. In 1976-77, scabies was recorded on red foxes in northern parts of Norway and spread to southern parts in a couple of years (Borg 1978; Mörner 1992; Kraabøl 2003). In Sweden, more than 50 $\%$ of the hunting organizations reported the disease in 1981 and reports increased to over $75 \%$ in 1983. Despite regional differences the overall population decline was of $50-90 \%$ (Lindström \& Mörner 1985; Lindström 1991; Mörner 1992), and populations in Norway and Sweden did not recover until the late 1980s and beginning of the 1990s (Lindström et al. 1994). This red fox population phenomenon may be viewed as a large scale experiment to reveal the importance of red fox predation on prey density. Many researchers have explored the effects of the reduced density of foxes (Lindström et al. 1994; Lindström et al. 1995; Selås 1998; Smedshaug et al. 1999). The studies indicate that the red fox is a keystone predator on small game species in Scandinavia. For example capercaillie (Tetrao urugallus), black grouse (T. tetrix), mountain hare (Lepus timidus), hazel grouse (Bonasa bonasia), willow grouse (Lagopus l. lagopus) and pine marten decreased significantly when the red fox populations recovered in the late 1980s (e.g. Danell \& Hörnfeldt 1987, Lindström et al. 1994; 1995; Smedshaug et al. 1999; Gundersen \& Rolstad 2000).

The prevalence of sarcoptic mange in European red fox populations is 14- $26 \%$ (Schoffel et al. 1991; Gortazar et al. 1998; Lassnig et al. 1998; Schuster et al. 2001; Sreter et al. 2003; Goldova et al. 2003; Balestrieri et al. 2006). These results rely on different sampling methods and may be biased both ways. Surveys of carcasses collected from road accidents, or from hunters may overestimate abundance because infested animals may more frequently expose themselves (Balestrieri et al. 2006). On the other hand, some foxes have a sub-clinical form of disease, which are not easy to detect from skin scrapings (Bornstein 2004).

In common with many parasitic diseases (Poulin 2007), it appears that a minority of individuals in a population harbor a large proportion of mites. These individuals may play a key role in determining the severity of mite hypersensitivity in groups by providing a source of repeated mite exposure. The environmental contamination is, in addition to direct physical contact between individuals, a source of scabies in domestic and wild canids. It is therefore proposed that dens and other site-specific locations represent important sources of contamination among red foxes during hunting season, like urban environments, cabin areas or waste depots. Site-specific fence entrance to waste depots or other narrow entrances in urban areas may act as contamination sources during summer. Further, environmental contamination source demands neither temporal synchrony nor physical contact between individuals and should be considered partly as a density-independent source of sarcoptic mange.

\section{Risk for threatened species}

There is a growing concern about wildlife and livestock diseases in general, and multi-host situations seem to be an increasing challenge for wildlife management and conservation (Gortázar et al. 1998, 2007). There is evidence from the Alps that sarcoptic mange outbreaks pose a threat to endangered species such as chamois (Rupicapra rupicapra) and ibex (Capra ibex) (Fernandez-Moran et al. 1997). In remnant or isolated populations, or in very low populations, severe mange outbreaks can have serious effect and cause extinction of populations as for example recorded from the red foxes on a Danish island (Henriksen et al. 1993). Both S. scabiei and N. cati occur on intermediate hosts, which can contribute to the spread of mange. The arctic fox population in Fennoscandia is threatened by extinction and classified as critically endangered on the Red List. Despite legal protection for more than 80 years, the population has not recovered. Conservation measures include a captive breeding program (Landa et al. 2011; Anonymous 2012), supplemental feeding (Angerbjörn et al. 2008) and culling of red foxes. The red fox has been identified as a major threat to the arctic fox, as it has been expanding its range into the mountains and is both a strong competitor and predator for the arctic fox (Rodnikova et al. 2011; Herfindal et al. 2010; Tannerfeldt et al. 2002; Linnell \& Strand 1999; Elmhagen et al. 2002; Frafjord et al. 1989; Pamperin et al. 2006). The red fox may also act as a transmission vector for $S$. scabiei to the arctic fox, with potentially devastating effects. The occurrence of scabies among arctic foxes occurred in 1986 in Sweden, but the small local population was caught and successfully treated (Mörner 1992). Carcasses and feeding stations may potentially act as sites for transmission and contamination, although hitherto this does not seem to represent a serious risk.

In 1999, five free-ranging lynx affected by scabies were found dead in the Alps in Switzerland (Ryser-Degiorgis et al. 2002). Two lynx were infected with $N$. cati, two with $S$. scabiei and one lynx was infected with both species. A few years earlier, an epidemic of sarcoptic mange among foxes was recorded in the northwestern Alps (Ochs et al. 1998) near the center of the affected lynx population. Domestic cats were also suspected vectors to the lynx population. At that time, the reintroduced lynx population (introduced in the 1970s) consisted of approximately 70 individuals with a high local density (Breitenmoser et al. 1998, 1999). There is an imminent 
risk for spread of scabies to threatened species as arctic fox and lynx because they compete for the same resources (habitats, prey and dens). Further research is needed to acquire more knowledge to prevent transmission and development of mange in arctic fox populations. More sporadic records of sarcoptic mange in solitary lynx as are observed several places. This is assumed to be related to intra-guild predation from lynx on red foxes (Kolodziej-Sobocinska et al. 2014), and calls for an improved surveillance strategy.

It is possible that the reduced red fox populations due to the outbreak of sarcoptic mange in the 1980s was advantageous to the arctic fox, as it possibly reduced the pressure of red foxes into the alpine habitats of arctic foxes. However, there are no data to support this statement (Dr. Nina E. Eide pers. comm.). Today, the red fox expand into mountain areas, and there are many examples that well-established arctic fox dens have been occupied by red fox (Hersteinsson \& Macdonald 1992; Frafjord 2003). There may be several reason for this expansion. A combined effect of elevated emigration rates of red foxes as a response to increased population density in the lowland are suggested. Further, the ongoing climate changes, and also increased amount of waste products from cabin areas and tourism industry in the mountains as well as the occurrence of disposal sites for organic products around cities, may contribute to the red fox expansion. However, scabies caused by both mites will probably spread slower in the colder mountain areas due to low population densities and no indirect transmission factors. Besides, infected foxes will die sooner in harsh alpine environments with low temperatures and fewer alternative foraging alternatives, thereby reducing the risk of an outbreak that may affect a larger part of the population.

\section{Concluding remarks}

Outbreaks of sarcoptic and notoedric mange have inflicted severe consequences on Fennoscandian wildlife during the last decades. Similar scenarios are also well known from other parts of the world. Detrimental scabies is a species-specific parasitic disease, which has the capacity to affect wildlife fauna through ecological cascading effects. Considering the wide-ranging effects on wildlife from individual to society level, it certainly calls for improved surveillance methods to detect outbreaks in the future. Moreover, there is a need for better tools to cope with developing outbreaks. The red fox is a key species in Fennoscandia because it is assumed to be a key opportunist predator on popular game species. Further, the red fox may be a transmission vector of sarcoptic mange to the threatened and fragmented arctic fox populations. We suggest systematic data collection from fox hunters on a county-level. Foxes shot during bait hunting seems to be the most proper collection method because baits attracts mangy foxes. The prevalence may be somewhat over-estimated by using this sampling method, but it is more important to register the existence of mangy foxes rather than focusing on a representative prevalence. Sufficient data collection would be annual hunting reports from bait hunters. Such reports from each county should be based on the hunter's ability to perform in situ diagnostic assessment based on characteristic clinical features displayed by infected foxes. When outbreaks are detected, representative samples of infected foxes should be gathered and subjected to veterinary investigations. The risk of devastating outbreaks of notoedric mange on lynx populations, on the other hand, seems to be limited. However, considering the outbreak in the Swiss Alps, lynx should be closely monitored in Fennoscandia. Lynx shot during licensed hunting should routinely undergo veterinary control for scabies symptoms.

Surprisingly, the literature covering wildlife effects of mange outbreaks are scarce compared to the large body of veterinarian literature covering livestock species and pets. This is true not only at a Fennoscandian level, but also world-wide. Considering the potential to learn more about coevolution of host-parasite relationships, and not to mention the detrimental and typically protracting effects inflicted by these mites on individual, population and society levels, we strongly argue that the disease should receive more attention by wildlife management authorities in Fennoscandia.

\section{REFERENCES}

Alonso de Vega FJ, Mendez de Vigo J, Ortiz Sanches C, MartinezCarrasco Pleite A, Albaladejo S, Ruiz de Ybanez Carnero MR. 1998. Evaluation of the prevalence of sarcoptic mange in slaughtered fattening pigs in southeastern Spain. Veterinary Parasitology 76: 203-209. doi: 10.1016/S0304-4017(97)00212-4

Andrews JRH. 1983. The origin and evolution of host associations of Sarcoptes scabiei and the subfamily Sarcoptinae Murray. Acarologia 24: 85-94.

Angerbjörn A, Henttonen H, Eide NE, Landa A, Nordén K, Meijer T. 2008. Saving the Endangered Fennoscandian Alopex lagopus. Final report LIFE03 NAT/S/000073, SEFALO.

Anonymous. 2000. Scabies management. Paediatrics and Child Health 6: 775-777.

Anonymous. 2012. Direktoratet for naturforvaltning. Fjellreven snart i hundre. http://www.dirnat.no/content/500044132/ Fjellreven-snart-i-hundre. (Accessed 22.11.2015)

Anonymous. 2015a. http://www.aavp.org/wiki/arthropods/ arachnids/astigmata/notoedres-cati/ (Accessed 22.11.2015)

Anonymous. 2015b. www.fcps.k12.va.us/Stratford LandingES/ Ecology/mpages/sarcoptic_mange_mite.htm (Accessed 22.11.2015)

Arlian LG. 1988. Survival of adults and developmental stages of Sarcoptes scabiei var. canis when off the host. Experimental and Applied Acarology 6: 181-187. doi: 10.1007/BF01193978

Arlian LG. 1989. Biology, host relations and epidemiology of Sarcoptes scabiei. Annual Reviews of Entomology 34: 139-161.

Arlian LG, Morgan MS, Vyszenski-Moher DL, Stemmer BL. 1994a. Sarcoptes scabiei: The circulating antibody response and induced immunity to scabies. Experimental Parasitology 78: 37-50. doi: 10.1006/expr.1994.1004

Arlian LG, Rapp CM, Vyszenski-Moher DL, Morgan MS. 1994b. 
Sarcoptes scabiei: Histopathological changes associated with acquisition and expression of host immunity to scabies. Experimental Parasitology 78: 51-63. doi: 10.1006/expr.1994.1005

Arlian LG, Rapp CM, Stemmer BL, Morgan MS, Moore PF. 1997. Characterization of lymphocyte subsets in scabietic skin lesions of naive and sensitized dogs. Veterinary Parasitology 68: 347258. doi: 10.1016/S0304-4017(96)01093-X

Arlian LG, Runyan RA, Achar S. 1984. Survival and infectivity of Sarcoptes scabiei var. canis and var. hominis. Journal of American Acad Dermatology 11: 210-215. doi: 10.1016/S01909622(84)70151-4

Arlian LG, Morgan MS, Rapp CM, Vyszenski-Moher DL. 1996. The development of protective immunity in canine scabies. Veterinary Parasitology 62: 133-142. doi: 10.1016/03044017(95)00854-3

Arlian LG, Morgan MS, Neal JS. 2003. Modulation of cytokine expression in human keratinocytes and fibroblasts by extracts of scabies mites. American Journal of Tropical Medicine and Hygiene 69: 652-656.

Arlian LG, Morgan MS, Paul CC. 2006. Evidence that scabies mites (Acari: Sarcoptidae) influence production of interleukin-10 and the function of T-regulatory cells (trl) in humans. Journal of Medical Entomology 43: 283-287. doi: 10.1603/0022-2585(2006)043[0283:ETSMAS]2.0.CO;2

Balestrieri AL, Remonti N, Ferrari A, Ferrari T, Valvo L, Robetto S, Orusa R. 2006. Sarcoptic mange in wild carnicores and its co-occurence with parasitic helminths in the Western Italian Alps. European journal of Wildlife Research 52; 196-201.

Baker PJ, Funk SM, Harris S, White PC. 2000. Flexible spatial organization of urban foxes, Vulpes vulpes, before and during an outbreak of sarcoptic mange. Animal Behaviour 59: 127-146. doi: 10.1006/anbe.1999.1285

Balic A, Bowles V, Meeusen, E. 2000. The immunobiology of gastrointestinal nematode infections in ruminants. Advances in Parasitology 45: 182-241. doi: 10.1016/S0065-308X(00)45005-0

Beck W. 2005. Animal parasites and dermatophytes as a cause of epizoonoses in humans. Praktische Tierarzt 86: 426-430.

Berilli F, D’Amelio S, Rossi L. 2002. Ribosomal and mitochondrial DNA sequence variation in Sarcoptes mites from different hosts and geographical regions. Parasitology Research 88: 772-777. doi: 10.1007/s00436-002-0655-y

Birk RW, Tebbe B, Schein E, Zouboulis CC, Orfanos CE. 1999. Pseudo-skabies durch Rotfuchs übertragen. Hautarzt 50: 127130 (in German).

Borg K, Christensson D, Fabiansson E, Kronevi T, Nilsson PO, Uggla A. 1976. Sarcoptic mange of red fox in Sweden. Svensk Jakt 8: 504-506 (in Swedish).

Borg K. 1978. Viltsykdommer. Oslo. Landbruksforlaget. 215 pp (in Norwegian).

Bornstein S, Morner T, Samuel WM. 2001. Sarcoptes scabiei and sarcoptic mange. In: Samuel WM, Kocan AA (eds). Parasitic diseases of wild animals. 2nd edition. Iowa State University Press. pp 107-119. doi: 10.1002/9780470377000.ch5

Bornstein S. 2004. Sarcoptic mange in pigs. Pig News Inf. 25: $11-24$.

Breitenmoser U, Breitenmoser-Würsten C, Capt S. 1998. Re-introduction and present status of the lynx (Lynx lynx) in Switzerland. Hystrix 10: 17-30.

Breitenmoser U, Breitenmoser-Würsten C, Capt S, Ryser A,
Zimmermann F, Angst C, Olsson P, Baumgartner H-J, Siegenthaler A, Molinari P, Laas J, Burri A, Jobin A, Weber J-M. 1999. Lynx management problems in the Swiss Alps. Cat News 30: 16-18.

Brook I. 2002. Secondary bacterial infections complicating skin lesions. Journal of Medical Microbiology 51: 808-812.

Brotowijoyo MD. 1987. Scabies pada hewan dan permasalahannya. Bulletin FKH UGM 7: 1-5.

Burgess I. 1994. Sarcoptes scabiei and scabies. Advanced Parasitology 33: 235-292. doi: 10.1016/S0065-308X(08)60414-5

Burkhart CG, Burkhart CN, Burkhart KM. 2000. An epidemiologic and therapeutic reassessment of scabies. Cutis 65: 233-240.

Burroughs RF, Elston DM. 2003. What's eating you? Canine scabies. Cutis 72: 107-109.

Cabrera R, Agar A, Dahl MV. 1993. The immunology of scabies. Sem Dermatol 12: 15-21.

Chakrabarti A. 1985. Some epidemiological aspects of animal scabies in human population. International Journal of Zoonoses 12: 39-52.

Chakrabarti A. 1986. Human notoedric scabies from contact with cats infested with Notoedres cati. International Journal of Dermatology 25: 646-648. doi: 10.1111/j.1365-4362.1986. tb04527. $\mathrm{x}$

Claerebout E, Vercruysse J. 2000. The immune response and evaluation of acquired immunity against gastrointestinal nematodes in cattle. A review. Parasitology 120: 25-42.

Cox FEG. 2001. Concomitant infections, parasites and immune responses. Parasitology 122: 23-38. doi: 10.1017/ S003118200001698X

Chosidow O. 2000. Scabies and pediculosis. The Lancet 355: 819822.

Curtis CF. 2004. Current trends in the treatment of Sarcoptes, Cheyletiella and Otodectes mite infestations in dogs and cats. Veterinary Dermatology 15: 108-114. doi: 10.1111/j.13653164.2004.00362.x

Danell K, Hörnfeldt B. 1987. Numerical responses by populations of red fox and mountain hare during an outbreak of sarcoptic mange. Oecologia 73: 533-536. doi: 10.1007/BF00379412

Danielssen DC, Boeck W. 1848. Traite de la Spedalsked ou Elephantiasis des Grecs. J. B. Balliere, Paris, 1848.

Davidson R, Bornstein S, Handeland K. 2008. Long-term study of Sarcoptes scabiei infection in Norwegian red foxes (Vulpes vulpes) indicating host/parasite adaption. Veterinary Parasitology 156: 277-283. doi: 10.1016/j.vetpar.2008.05.019

Davis DP, Moon, RD. 1990a. Dynamics of swine mange: A critical review of the literature. Journal of Medical Entomology 27: 727-737.

Davis DP, Moon, RD. 1990b. Density of itch nite, Sarcoptes scabiei (Acari; Sarcoptidae) and temporal development of cutaneous hypersensitivity in swine mange. Veterinary Parasitology 85: 285-293. doi: 10.1016/0304-4017(90)90040-I

Deem SL, Noss AJ, Cuellar RL, Villarroel R, Linn MJ, Forrester DJ. 2002. Sarcoptic mange in free-ranging pampas foxes in the Gran Chaco, Bolivia. Journal of Wildlife Diseases 38: 625-628.

Dobias T. 1981. Erfolgreiche Behandlung einer Räudeerkrankung (Notoedes cati) bei Luchsen. In: Verhandlungsbericht des XXIII Internationalen Symposiums über die Erkrankungen der Zootiere, Halle-Saale, Germany. pp. 253-255.

Droogan J. 1999. Treatment and prevention of head lice and 
scabies. Nursery Times 95: 44-45.

Dunlop JA. 1996. Evidence for a sister group relationship between Ricinulei and Trigonotarbida. Bull Brit. Arachnol Soc 10: 193204.

Elmhagen B, Tannerfeldt M, Angerbjörn A. 2002. Food-niche overlap between arctic and red foxes. Canadian Journal of Zoology 80: 1274-1285. doi: 10.1139/Z02-108

Evans GO. 1992. Principles of Acarology. Cambridge, UK. CAB International, Wallingford, Oxon OX10 8DE.

Fain A. 1968. Etude de la veriabilitè de Sarcoptes scabiei avec une rèvision des Sarcoptidae. Acta Zool. Pathol Antverp 47: 1-196.

Fain A. 1978. Epidemiological problems of scabies. International Journal of Dermatology 17: 20-30. doi: 10.1111/j.1365-4362.1978. tb06040.x

Fain A. 1994. Adaptation, specificity and host-parasite coevolution in mites (Acari). International Journal of Parasitology 24: 12731283. doi: 10.1016/0020-7519(94)90194-5

Fernandez-Moran JS, Gomez S, Ballesteros F, Quiros P, Benito J, Feliu C, Nieto JM. 1997. Epizootiology of sarcoptic mange in a population of cantabrian is (Rupicapra pyrenaica parva) in Northwestern Spain. Veterinary Parasitology 73: 163-171. doi: 10.1016/S0304-4017(97)00061-7

Fields PG. 1992. The control of stored-product insects and mites with extreme temperatures. Journal of Stored Products Research 28: 89-118. doi: 10.1016/0022-474X(92)90018-L

Forchhammer MC, Asferg T. 2000. Invading parasite causes structural shift in red fox dynamics. Proceedings Royal Society London B 267: 779-786. doi: 10.1098/rspb.2000.1071

Frafjord K, Becker D, Angerbjørn A. 1989. Interactions between arctic and red foxes in Scandinavia - predation and aggression. Arctic 42: 354-356.

Frafjord K. 2003. Ecology and use of arctic fox Alopex lagopus dens in Norway: tradition overtaken by interspecific competition? Biological Conservation 111: 445-453. doi: 10.1016/S00063207(02)00314-2

Goldová M, Lazar P, Letková V. 2001. Sarcoptic mange in wild red foxes (Vulpes vulpes) (a mini survey). Folia Veterinaria 45, No. 1, 2001.

Goldova M, Lazar P, Letkova V, Kocisova A, Kurlic J, Soroka J. 2003. Occurrence of Sarcoptes scabiei in wild foxes (Vulpes vulpes) in East Slovakia. In: Espositi L, Gasparrini B (eds). Third International Symposium on Wild Fauna, 24-28 May 2003, Ischia, Italy.

González-Candela M, León-Vizcaíno L, Cubero-Pablo MJ 2004. Population effects of sarcoptic mange in barbary sheep (Ammotragus lervia) from Sierra Espuña Regional Park, Spain. Journal of Wildlife Diseases 40: 456-465.

Gortázar C, Villafuerte R, Lucientes J, Fernandez-De-Luco D. 1998. Habitat related differences in helminth parasites of red foxes in Ebro Valley. Veterinary Parasitiology 80: 75-81. doi: 10.1016/S0304-4017(98)00192-7

Gortázar C, Ferroglio E, Höfle U, Frölich K, Vicente J. 2007. Diseases shared between wildlife and livestock: a European perspective. European Journal of Wildlife Research 53: 241-256. doi: 10.1007/s10344-007-0098-y

Guaguère E. 1999. Ectoparasitic skin diseases. In: Guaguère E, Prèlaud (eds). A practical guide to feline dermatology. Merial, Paris, France. Chapters 3.1-3.14.

Gundersen V, Rolstad J. 2000. Rev og mår i boreal barskog: har habitatfragmenteringen medført økt predasjonstrykk. Fauna 53: 186-198. (In Norwegian)

Haas N, Wagemann B, Hermes B, Henz BM, Heile C, Schein E. 2005. Crossreacting IgG antibodies against fox mite antigens in human scabies. Archives in Dermatology Research 296: 327-331. doi: 10.1007/s00403-004-0524-x

Hay RJ. 2004. Scabies - learning from the animals. Journal of European Academy of Dermatology and Venereology 18: 129130. doi: 10.1111/j.1468-3083.2004.00847.x

Heilesen B. 1946. Studies on Acarus scabiei and scabies. Acta Dermatology Venereology 26: 26-30.

Henriksen P, Dietz HH, Henriksen SA, Gjelstrup P. 1993. Sarcoptic mange in red fox in Denmark. A short report. Dansk Vettidsskr 76: $12-13$

Herfindal I, Linnell JD, Elmhagen B, Andersen R, Eide NE, Frafjord K, Henttonen H, Kaikusalo A, Mela M, Tannerfeldt M, Dalén L, Strand O, Landa A, Angerbjörn A. 2010. Population persistence in a landscape context: the case of endangered arctic fox populations in Fennoscandia. Ecography 33: 932-941. doi: 10.1111/j.1600-0587.2009.05971.x

Hersteinsson P, Macdonald DW. 1992. Interspecific competition and the geographical distribution of red and arctic fox Vulpes vulpes and Vulpes lagopus. Oikos 64:505-515. doi: 10.2307/3545168

Heukelbach J, Feldmeier H. 2006. Scabies. The Lancet 367: 17671774. doi: 10.1016/S0140-6736(06)68772-2

Holt G, Berg C. 1990. Sarcopteskab hos rødrev og andre viltlevende rovdyr i Norge. Norsk Veterinærtidskrift 102: 427-432 (in Norwegian).

Hubler WR. 1976. Epidemic Norwegian scabies. Archives in Dermatology 112: 179.

Huffam SE, Currie BJ. 1998. Ivermectin for Sarcoptes scabiei hyperinfestation. International Journal of Infection Diseases 2: 152-154. doi: 10.1016/S1201-9712(98)90118-7

Hulbert TV, Larsen RA. 1992. Hyperkeratotic (Norwegian) scabies with gram-negative bacteremia as the initial presentation of AIDS. Clinical Infection Diseases 14: 1164-1165.

Jeu M, Xiang P. 1982. Discovery of Sarcoptes scabiei infesting lynx in Chongquin, China. Zoological Research 3: 310.

Johnston DE. 1982. Acari. In: Parker SP (ed). Synopsis and classification of living organisms. McGraw-Hill, New York. p. 111.

Kemp DJ, Walton SF, Harumal P, Currie BJ. 2002. The scourge of scabies. Biologist 49: 19-24.

Kethley JB, Norton RA, Bonamo PM, Shear WA. 1979. A terrestrial alicorhagiid mite (Acari: Acariformes) from the Devonian of New York. Micropaleontology 35: 367-373. doi: $10.2307 / 1485678$

Klein Serieys LE, Foley J, Owens S, Woods L, Boydston E, Lyren L, Poppenga R, Clifford DL, Stephenson N, Rudd J, Riley S. 2013. Serum chemistry, hematologic and post-mortem findings in bobcats (Lynx rufus) with notoedric mange. Journal of Parasitology 99: 989-996. doi: 10.1645/12-175.1

Kolodziej-Sobocinska M, Zalewski A, Kowalczyk R. 2014. Sarcoptic mange vulnerability in carnivores of the Bialowieza Primeval Forest, Poland: underlaying determinant factors. Ecological Restoration 29: 237-244. doi: 10.1007/s11284-0131118-X

Kraabøl M. 2003. Rev og revejakt. Bokklubben Villmarksliv/ Friluftsforlaget (in Norwegian). 
Krantz GW. 1978. A manual of Acarology. 2nd edition. Oregon State University Bookstores, Corvallis.

Kuhn C, Lucius E, Matthes HF, Meusel G, Reich B, Kalinna BH. 2008. Characterization of recombinant immunoreactive antigens of the scab mite Sarcoptes scabiei. Veterinary Parasitology 153: 329-337. doi: 10.1016/j.vetpar.2008.02.007

Lalli PN, Morgan MS, Arlian LG. 2004. Skewed Th1/Th2 immune response to Sarcoptes scabiei. Journal of Parasitology 90: 219226. doi: 10.1645/GE-214R

Landa A, Tovmo M, Merås R, Eide NE, Flagstad Ø, Andersen R. 2011. Avlsprogrammet for fjellrev. Trondheim. Årsrapport 2010.- NINA Rapport 603. 36 p.

Lassnig H, Prosl H, Hinterdorfer F. 1998. Zur Parasitenfauna des Rotfuchses (Vulpes vulpes) in der Steinmark. Wiener Tieraztl Wschr. 85: 116-122 (in German).

Lindström E, Mörner T. 1985. The spreading of sarcoptic mange among Swedish red foxes (Vulpes vulpes) in relation to fox population dynamics. Revue d'ecologie 40: 211-216.

Lindström E, Andrèn H, Angelstam P, Cederlund G, Hörnfeldt B, Jäderberg L, Lemnell P-A, Martinsson B, Sköld K, Swenson JE. 1994. Disease reveals the predator: sarcoptic mange, red fox predation, and prey populations. Ecology 75: 1042-1049. doi: $10.2307 / 1939428$

Lindström E, Brainerd SM, Helldin JO, Overskaug K. 1995. Pine marten red fox interactions: a case of intraguild predation? Ann. Zool. Fenn. 32: 123-130.

Lindquist EE. 1984. Current theories on the evolution on the evolution of major groups of Acari and on their relationship with other groups of Arachnidae, with consistent implications for their classification. In: Griffiths DA, Bowman CE (eds). Acarology VI (Volume 1). New York. John Wiley \& Sons. pp. 28-62.

Linnell JDC, Odden J, Pedersen V, Andersen R. 1998. Records of intra-guild predation by Eurasian lynx. Canadian FieldNaturalist 112: 707-708.

Linnell JDC, Strand O. 1999. Use of dens by red Vulpes vulpes and arctic Alopex lagopus foxes in the alpine environments: Can intraspecific competition explain the non-recovery of Norwegian arctic fox population? Wildlife Biology 5: 167-176.

Little SE, Davidson WR, Howerth EW, Rakich PM, Nettles, VF. 1998. Diseases diagnosed in red foxes from the southeastern United States. Journal of Wildlife Diseases 34: 620-624.

Martin R, Handasyde K, Skerratt LF. 1998. Current distribution of sarcoptic mange in wombats. Australian Veterinary Journal 76: 411-414. doi: 10.1111/j.1751-0813.1998.tb12391.x

McCarthy JS, Kemp DJ, Walton SF, Currie BJ. 2004. Scabies: More than just an irritation. Postgraduate Medical Journal 80: 382-387.

Mellanby K. 1944. The development of symptoms, parasitic infection and immunity in human scabies. Parasitology 35 : 197-206.

Mellanby K. 1985. Biology of the parasite. In: Orkin M, Maibach HI (eds). Cutaneous infestations and insect bites. New York. Marcel Dekker. pp 9-18.

Millán J. 2010. First description of sarcoptic mange in wild European rabbit (Oryctolagus cuniculus). Short Communication. European Journal of Wildlife Research 56:455-457. doi:10.1007/ s10344-009-0347-3

Mitra M, Mahanta SK, Sen S, Ghosh C, Hati AK. 1993. Sarcoptes scabiei in animals spreading to man. Tropical Geographical Medicine 45: 142-143.

Morsy TA, Bakr ME, Ahmed MM, Kotb MM. 1994. Human scabies acquired from a pet puppy. Journal of Egypt Society of Parasitology 24: 305-308.

Mörner T. 1984. The epizootic outbreak of sarcoptic mange in Swedish red foxes (Vulpes vulpes). In: Proceedings of the 4th international conference of the Wildlife Disease Association, Sydney, Australia, 1981.

Mörner T. 1992. Sarcoptic mange in Swedish wildlife. Revue Scientifique et Technique Office International des Epizooties 11: 1115-1121.

Mörner T, Christensson D. 1984. Experimental infection of red foxes (Vulpes vulpes) with Sarcoptes scabiei var. vulpes. Veterinary Parasitology 15: 159-164. doi:10.1016/03044017(84)90031-1

Newman TJ, Baker PJ, Harris S. 2002. Nutritional condition and survival of red foxes with sarcoptic mange. Canadian Journal of Zoology 80: 154-161. doi: 10.1139/Z01-216

Nimmervoll H, Hoby S, Robert N, Lommano E, Welle M, RyserDegiorgis M-P. 2013. Pathology of Sarcoptic mange in red foxes (Vulpes Vulpes): Macroscopic and histologic characterization of three disease stages. Journal of Wildlife Diseases, 49: 91-102. doi: 10.7589/2010-11-316

Norton RA, Bonamo PM, Grierson JD, Shear WA. 1988. Oribatid mite fossils from a terrestrial Devonian deposit near Gilboa, New York. Journal of Paleontology 62: 259-269.

Nisbet AJ, Huntley, JF. 2006. Progress and opportunities in the development of vaccines against mites, fleas and myiasiscausing flies of veterinary importance. Parasite Immunology 28: 165-172. doi: 10.1111/j.1365-3024.2006.00803.x

Ochs H, Müller U, Fischer C. 1998. Fuchsraüde kehrt in die Sweitz zurück. Jagd und Natur 11: 35-36 (in German).

Oleaga A, Casais R, González-Quirós P, Prieto M, Gortázar C. 2008a. Sarcoptic mange in red deer from Spain: Improved surveillance or disease emergence? Veterinary parasitology 154: 103-113. doi:10.1016/j.vetpar.2008.03.002

Oleaga A, Balseiro A, Gortázar C. 2008b. Sarcoptic mange in two roe deer (Capreolus capreolus) from Northern Spain. European Journal of Wildlife Research 54: 134-137. doi: 10.1007/s10344007-0105-3

Orion E, Marcos B, Davidovici B, Wolf R. 2006. Itch and scratch: Scabies and pediculosis. Clinics in Dermatology 24: 168-175. doi:10.1016/j.clindermatol.2005.11.001

Pamperin NJ, Follmann EH, Petersen B. 2006. Interspecific killing of an arctic fox by a red fox at Prudhoe Bay, Alaska. Arctic 59: 361-364.

Pence DB, Castro SD, Samuel WM. 1975. Variation in the chaetotaxy and denticulation of Sarcoptes scabiei (acarina; Sarcoptidae) from wild canids. Acarologia 17: 160-165.

Pence DB, Mattews FD, Windberg LA. 1982. Notoedric mange in the bobcat, Felis rufus, from southern Texas. Journal of Wildlife Diseases 18: 47-50.

Pence DB, Windberg LA, Pence BC, Sprowls R. 1983. The epizootiology and pathology of sarcoptic mange in coyotes, Canis latrans, from southern Texas. Journal of Parasitology 69: 1100-1115. doi:10.2307/3280873

Pence DB, Windberg F. 1994. Impact of a sarcoptic mange epizootic on a coyote population. Journal of Wildlife Management 58: 
624-633.

Pence DB, Teewes ME, Schindle DB, Tunkkari PS. 1995. Notoedric mange in an ocelot (Felis pardalis) from Southern Texas. Journal of Wildlife Diseases 31: 558-561.

Pence DB, Ueckerman E. 2002. Sarcoptic mange in wildlife. Revue Scientifique et Technique De L Office International Epizooties. 21: 385-398.

Poulin R. 2007. Evolutionary Ecology of Parasites (2nd Edition). Princeton University Press, New Jersey.

Ramos-e-Silva M. 1998. Giovan Cosmito Bonomo 16631696: Discoverer of the etiology of scabies. International Journal of Dermatology 37: 625-630. doi: 10.1046/j.13654362.1998.00400 1.x

Rodnikova A, Ims RA, Sokolov A, Skogstad G, Sokolov V, Shtro V, Fuglei, E. 2011. Red fox takeover of arctic fox breeding den: an observation from Yamal Peninsula, Russia. Polar Biology 34: 1609-1614. doi: 10.1007/s00300-011-0987-0

Ryser-Degiorgis M-P, Ryser A, Bacciarini LN, Angst C, Gottstein B, Janovsky M, Breitenmoser U. 2002. Notoedric and sarcoptic mange in free-ranging Lynx from Switzerland. Journal of Wildlife Diseases 38: 228-232.

Schoffel I, Schein E, Wittstatt E, Hentcshe J. 1991. Zur Parasitenfauna des Rotfuchses in Berlin (West). Berliner Und Munch Tierarztliche Wochenschrift 114: 193-196 (in German).

Schultz JW. 1990. Evolutionary morphology and phylogeny of Arachnology. Cladistics 6: 1-38.

Schuster R, Wanjek C, Bartnik C, Wittstatt U, Baumann M, Schein E. 2001. Leberegelbefal und Râude bein Rotfuchs in Berlin. Berliner Und Munch Tierarztliche Wochenschrift 114: 193-196 (in German).

Schmitt SM, Cooley TM, Friedrich PD. 1987. Clinical mange of the black bear (Ursus americanus) caused by Sarcoptes scabiei (Acarina, Sarcoptidae). Journal of Wildlife Diseases 23: 162-165.

Selås V. 1998. Does food competition from red fox (Vulpes vulpes) influence the breeding density of goshawk (Accipiter gentilis)? Evidence from a natural experiment. Journal of Zoology 246: 325-335. doi: 10.1111/j.1469-7998.1998.tb00162.x

Skerratt LF, Martin RW, Handasyde KA. 1998. Sarcoptic mange in wombats. Australian veterinary Journal 76: 408-410. doi:10.1111/j.1751-0813.1998.tb12389.x

Skerratt LF, Campbell NJH, Murrell S, Walton S, Kemp D, Barker SC. 2002. The mitochondrial $12 \mathrm{~S}$ gene is a suitable marker of populations of Sarcoptes scabiei from wombats, dogs and humans in Australia. Parasitology Research 88: 376-379. doi: 10.1007/s00436-001-0556-5

Skerratt LF. 2003a. Clinical response of captive common wombats (Vombatus ursinus) infected with Sarcoptes scabiei var. vombati. Journal of Wildlife Diseases 39: 179-192.

Skerratt LF. 2003b. Cellular response in the dermis of common vombats (Vombatus ursinus) infected with Sarcoptes scabiei var. vombati. Journal of Wildlife Diseases 39: 103-202.

Smedshaug CA, Selås V, Lund SE, Sonerud GA. 1999. The effects of a natural reduction of red fox Vulpes vulpes on small game hunting bags in Norway. Wildlife biology 5: 157-166.

Sokolova TV, Lange AB. 1992. The parasite-host spesificity of the itch mite Sarcoptes scabiei (Acariformes; Sarcoptidae) in man and animals. Parasitologia 26: 97-104.

Soll MD, d'Assonville JA, Smith CJZ. 1992. Efficacy of topically applied invermectin against sarcoptic mange (Sarcoptes scabiei var. bovis) of cattle. Parasitiology Research 78: 102-122. doi: 10.1007/BF00931652

Soulsbury CD, Iossa G, Baker PJ, Cole NC, Funk SM, Harris S. 2007. The impact of sarcoptic mange Sarcoptes scabiei on the British fox Vulpes vulpes population. Mammal Rev. 37: 278-296. doi: 10.1111/j.1365-2907.2007.00101.x

Sreter T, Szell Z, Varga I. 2003. Ectoparasite infestation of red foxes (Vulpes vulpes) in Hungary. Veterinary Parasitology 115: 69-83. doi: 10.1016/S0304-4017(03)00216-4

Stromberg PC, Fisher WF. 1986. Dermatopathology and immunity in experimental Psoroptes ovis (Acari: psoroptidae) infestationof naïve and previously exposed Hereford cattle. American Journal of Veterinary Research 47: 1551-1560.

Stromberg PC, Guillot FS. 1989. Pathogenesis of psoroptic scabies in Hereford calves. American Journal of Veterinary Research 50: 594-601.

Sunde P, Overskaug K, Kvam T. 1999. Intraguild predation of lynxes on foxes: evidence of interference competition? Ecography 22: 521-523. doi: 10.1111/j.1600-0587.1999.tb01281.x

Tannerfeldt M, Elmhagen B, Angerbjörn A. 2002. Exclusion by interference competition? The relationship between red and arctic foxes. Oecologia 132: 213-220. doi: 10.1007/s00442-0020967-8

Tarigan S. 2003a. Dermatopathology of caprine scabies and protective immunity in sensitised goats against Sarcoptes scabiei infestation. Jurnal Ilmu Ternak dan Veteriner 7: 265-271.

Tarigan S. 2003b. Histopathological changes in naïve and sensitised goats caused by Sarcoptes scabiei. Jurnal Ilmu Ternak dan Vereriner 8: 114-121.

Tarigan S, Huntley JF. 2005. Failure to protect goats following vaccination with soluble proteins of Sarcoptes scabiei: Evidence for a role for $\operatorname{IgE}$ antibody in protection. Veterinary Parasitology 133: 101-109. doi: 10.1016/j.vetpar.2005.03.044

Todd AW, Gunson JR, Samuel WM. 1981. Sarcoptic mange: An important disease in coyotes and wolves of Alberta, Canada. In: Proceeding from Worldwide Furbearer Conference. Frostburg, Maryland. pp 706-729.

Van den Broek AH, Huntley JF. 2003. Sheep scab: The disease pathogenesis and control. Journal of Comparative Pathology 128: 79-91. doi: 10.1053/jcpa.2002.0627

Voigt TF. 2005. Acari - scabies pathogen in dogs and cats. Kleintierpraxis 50: 725-727 (in German).

Walker GJ, Johnstone PW. 2000. Interventions for treating scabies. Cochrane Database Syst. Rev. CD000320.

Walker E, Stacheki J (eds). 1996. Livestock pest management, Category 1D. A training manual for commercial applicators. Chapter 3: 45-59. pp 122.

Walton SF, Holt DC, Currie BJ, Kemp DJ. 2004. Scabies: New future for a neglected disease. Advances in Parasitology 57: 309-376.

Walton SF, Choy JL, Bonson A, Valle A, McBroom J, Taplin D, Arlian LG, Mathews JD, Currie BJ, Kemp DJ. 1999. Genetically distinct dog-derived and human-derived Sarcoptes scabiei in scabies-endemic communities in northern Australia. American Journal of Tropical Medicine Hygiene 61: 542-547.

Weygoldt P. 1997. Evolution and systematics of the Chelicerata. In: Sabelis MW, Bruin J, van der Geest A, Davids C (eds). Proceedings from the Third Symposium European Association of Acarologists, Exp. Appl. Acarol. Amsterdam, July 1996. 
Weygoldt P, Paulus HF. 1979. Untersuchungen zur morphologie, taxonomie und phylogenie der Chelicerata. 2. Cladogramme und die entfaltung der Chelicerata. Zeitschrift für Zoologische Systematik und Evolutionforschung 17: 177-200 (in German).

Wilson K, Bjornstad ON, Dobson AP, Merler S, Poglayen G, Randolph SE, Read AF, Skorping A. 2001. Heterogeneities in macroparasite infections: Patterns and processes. In: Hudson PJ, Rizzoli PJ, Grenfell A, Heesterbeck H, Dobson AP (eds). The ecology of wildlife diseases. Oxford University Press. p 198.

Editorial responsibility: Torkild Bakken.

This article is open-access and distributed under the terms of the Creative Commons Attribution 4.0 International license. This permits all non-commercial use, distribution, and reproduction in any medium, provided the original work is properly cited.

(http://creativecommons.org/licenses/by/4.0/). 